\title{
THE CASE FOR RULEMAKING BY LAW ENFORCEMENT AGENCIES $\dagger$
}

\author{
Geraid M. Caplan*
}

\section{INTRODUCTION}

Over the last five years, there has developed a heightened awareness of the benefits that would accrue to law enforcement from fashioning policy in major areas of public concern. The National Crime Commission, with its persistent exhortation to police officials "to develop and articulate clear policies aimed at guiding or governing the way policemen exercise their discretion on the street,"1 and the standards of the American Bar Association's Committee on the Urban Police Function ${ }^{2}$ have highlighted the promise of rulemaking by police agencies. The promise is twofold: increased effectiveness in reducing rising crime rates and delivering critical community services; and, at the same time, an improved system of regulating police conduct. To those who have been disappointed by the lack of success in reducing crime, rulemaking, ${ }^{3}$ with its more sophisticated use of the law to advance police goals, offers some hope for better crime control. To others, disenchanted with existing mechanisms for promoting police

TThis essay is an expanded version of a proposal, "Rulemaking in Law Enforcement Agencies: A Proposal for a Police Administrative Law Center," submitted to the Police Foundation for funding in late I97I and funded in January, I972. Under the terms of the grant, the Police Foundation awarded the law school at Arizona State University $\$ 267,048$ for two years to establish a project on law enforcement policy and rulemaking to assist approximately ten municipal police departments across the country in the preparation of rules. That part of the proposal which deals with the mechanics of identifying topics for rulemaking, liaison with police officials from participating agencies, and implementation of the rules has been deleted from this article. A copy of the full proposal may be obtained by writing directly to the author.

* Professor of Law, Arizona State University.

1 The Report of U.S. Pres. Comm. on Law Enforcement and Administration of Justice, The Challenge of Crime in a Free Society ro3 (1967). Cf. Ali Modei Code of Pre-Arraganment Procedore $\$$ I.03 (Tent. Draft No. I, I966); Report of National Advisory Commission on Civil DisORDERS, $164-65$ (1968).

The leading administrative law commentator, Professor Kenneth $C$. Davis, writing about the police, has recently stated, "No other federal, state, or local agency, so far as I know, delegates so much power to subordinates. No other agency, so far as I know, does so little supervising of vital policy determinations which directly involve justice or injustice to individuals." K. Davis, Discremonari Justice 88 (Ig69). Cf. Transcript of Remarks of Warren E. Burger, Chief Justice of the United States, at FBI National Academy Graduation Ceremony, November 3, I97r.

2 See generally ABA Comm. on the Police Function, Standards Relating to the Urban Poitce Funcrion, Part IV, Law Enforcement Policymaking (Tent. Draft, March, x972).

'The terms "rule" and "rulemaking" are not used here in the same sense that they are employed in the Administrative Procedure Act. Both terms have been defined in a number of ways and no attempt will be made here to posit a particular definition. For the purposes of this essay, Professor Fuchs' definition of rulemaking may be borrowed: ". . . the issuance of regulations or the making of determinations which are addressed to indicated but unnamed and unspecified persons or situations." Fuch , Procedure in Administrative Rule-Making, 52 HARv. L. Rev. 259, 265 (1938). Similarly, no attempt will be made to specify the elements of the rulemaking process, except in two particulars: ( $x$ ) publication in the sense of easy availability to interested persons is essential; and (2) there need not be any kind of participation by private parties. 
responsiveness and accountability-for example, the exclusionary rule, conventional tort remedies, and civilian complaint review boards-rulemaking, with its implication of visible standards and principles open to community scrutiny, provides an avenue for more sensitive law enforcement and improved community relations.

In the criminal justice field, the problem of defining issues is particularly acute. Issues of lesser importance have a tendency to become swollen to such a degree that they force more fundamental matters out of the public eye. Since only parts of a subject as complex as crime can emerge for public debate, the task is to single out the "correct" issues- "correct" in the sense that they are directed to institutional change and system reform rather than to personalities, idiosyncratic events, or symbolic matters of the moment. Law enforcement rulemaking is likely to be one of these "correct" issues.

Historically, law enforcement agencies have been neither bold nor vigorous in the development of policy. They have responded to the dictates of others, most notably the judiciary, rather than acting as initiators of policies. As a result, they have not developed in ways similar to that large and varied host of administrative agencies that routinely issue policy statements to guide their own employees and the general public. This is not to suggest that law enforcement agencies have entirely neglected policymaking. It is quite obvious that no large bureaucracy can carry out its day-to-day schedule without a multitude of operating policies. In the police world, however, policy formulation has been a selective process which is confined to narrow boundaries and to safe areas where discretion is recognized, experience is long, and staff expertise to research and design the policy is available. With respect to the care of equipment, off-duty behavior, the scheduling of court appearances, the handling of prisoners and prisoners' property, and-more recently - the use of the service revolver, many police departments have fashioned rules that instruct the men how to proceed. Some of these efforts reflect considerable skill in draftsmanship and have had a profound impact on street practices. But, as the National Crime Commission points out, they rarely embrace "the hard choices a policeman must make every day." They do not go to the "heart of police work." They do not affect those problems which determine "to a large degree the safety of the community, the attitude of the public toward the police and the substance of court rulings on police procedure."

For example, police agencies avoid writing policies governing criminal investiga-

\footnotetext{
'The Report of U.S. Pres. Comm. on Law Enforcenent and Administration of Justice, The Challenge of Crime in a Free Socrety ro3 ( 1967 ). In criticizing police agencies for their failure to develop policy, it is only fair to measure their performance, not in the abstract, but in comparison with other agencies. While there are some outstanding examples of administrative agencies that have achieved excellence in rulemaking, for example, the Internal Revenue Service, there are far many more that have done no more than the average municipal police agency. Among this latter group are agencies with highly qualified staffs, some composed primarily of professionals. For example, Professor Davis refers to the functioning of the United States Parole Board as an "outstanding example of completely unstructured discretionary power," and he concludes that it operates in such a manner that "even the most flagrant abuse of discretion is likely to go uncorrected." DAvis, supra note 1 , at I26, I28.
} 
tions, although everyone recognizes this area to be of central importance. Few attempts have been made to treat particular court decisions as integral parts of a larger body of law and then to reduce those decisions, which are quite numerous and not entirely consistent with one another, to a short set of clear rules for the investigating officer to follow. In communicating the meaning of recent judicial decisions to the force, the precise instruction of the general order approach (employed on such matters as the care of equipment, handling of stray dogs, towing away of abandoned automobiles, the personal conduct of officers on and off duty) almost invariably yields to a looser, vaguer format. Often the instrument is a training bulletin or a legal memorandum that recites the facts of a particular case, notes the various arguments on both sides, states the holding of the case, and perhaps even notes the logic of the dissent-particularly if the minority's position supports the action taken by the police.

There have been some notable exceptions, however, which demonstrate that rulemaking is a feasible approach to upgrading the quality of criminal investigation. For example, in such critical areas as the eyewitness identification of suspects ${ }^{5}$ (on the scene, through photographs, or at a lineup) and automobile searches ${ }^{6}$ (including probable cause searches, searches incident to an arrest, traffic stops, and impoundments and forfeitures) the Metropolitan Police Department of the District of Columbia has promulgated specific orders. These orders are designed to be lucid, direct, and concise in order to guide police behavior in difficult situations. Before they were authored, there was little available to assist the men other than an infrequent lecture from an assistant prosecutor or an occasional general bulletin read at roll call training.

\section{THE IMPACT OF RULEMAKING}

\section{A. Effect on the Individual Officer}

The impact of rulemaking on the patrolman can scarcely be overstated. Operating under the protective umbrella of department rules, the individual police officer would no longer be on his own to interpret a given court decision, group of decisions, or statute. His discretion would be channelled by carefully researched and articulated rules-rules formulated in categories meaningful to a policeman, rather than law textbook groupings not related to the situations likely to be encountered on the next tour of duty.

\footnotetext{
'District of Columbia Metropolitan Police Department, Memorandum Order No. I6 (Series I970).

${ }^{6}$ District of Columbia, Metropolitan Police Department, General Order No. 23 (Series 1971).

7 The reader may also consult the statewide "policy statement" on "stop-and-frisk" and "knockknock" laws issued by the New York State Combined Council on Law Enforcement Officials in 1964, and reprinted in full in the President's Commission on LAw Enforcement aNd ADMinistration of Justice, TASK Force Report: The Police 38-4I (I967) [hereinafter cited as TASK Force].
} 
The policeman who follows the department rules-even those subsequently voided by the courts-is likely to be immune from sanctions such as a civil suit for false arrest. The court will be evaluating not only his particular action but also the administrative policy of the department. Its first question will be whether the policeman adhered to that policy; and, secondly, the court will review whether that policy was reasonable and in accord with Constitutional standards. "If the administrative policy is wrong, reconsideration of the policy is called for. If the policy is proper and the conduct of the officer is wrong, the need is for reevaluation of training, intradepartmental communication, and methods of supervision and control." In this manner, responsibility is pinpointed where it belongs, at the level of the top officials of the agency and the municipality. Thus, the individual officer no longer carries the heavy weight of choosing at his peril the right course of action. Where there is sound policy, his officials have "backed him up."

Of course, no set of guidelines, no matter how well drafted, will service the officer on the street on all occasions. Inevitably, the general rule will encounter situations not envisioned by its drafters and require adjustment in order to avoid injustice. As Chief Justice Burger has recently pointed out:

No law book, no lawyer, no judge can really tell the policeman on the beat how to exercise this discretion perfectly in every one of the thousands of different situations that can arise in the hour-to-hour work of the policeman. Yet we must recognize that we need not choose between no guidelines at all and perfect guidelines. There must be some guidance by way of basic concepts that will assist the officer in these circumstances. ${ }^{9}$

\section{B. Effect on the Department}

Apart from the advantages to the individual officer, rulemaking affords the Department as a whole the opportunity to take the lead in developing policy that is sensible from the perspective of law enforcement. For example, the $1970 \mathrm{Memo}$ randum Order No. 16 on eyewitness identification issued by the Metropolitan Police Department fashions directives in certain areas where the courts of the District of Columbia have not yet ruled and where policy is not fully defined. To the extent that the order anticipates the case law, the Department will have had a positive influence on appellate court decision making. In other areas Memorandum Order No. 16 does not seek to use the full authority granted by the case law; it surrenders certain powers that are not seen as needed or helpful, even though granted by the

\footnotetext{
${ }^{3}$ Aba Comar. on the Police Function, Standards Relating to the URban Police Function, Standard 4.4, Comment (Tent. Draft No. 33, March, 1972).

${ }^{\circ}$ Burger, supra note $I$. The Chief Justice added that although the exercise of discretion was basically "a matter of common sense and sound judgment, .. . one man's common sense may be another man's mistake. Hence this need for carefully devised basic standards to guide the exercise of this discretion, and second, for careful and comprehensive training of officers before they are thrust into situations that would often baffle the wisest judge. We judges can hear arguments, read briefs, study, consult each other before we pass on whether there was probable cause for a particular police act; but the policeman often has only seconds to decide and act."
} 
courts, and establishes procedures deemed equally or more effective. The eyewitness identification order illustrates that even in an area of the law that appears to be saturated by judicial decisions there is much uncharted terrain for the agency to map.

The promise of the Order is that it will enable more policemen to conduct investigations in which the identifications secured will pass court scrutiny. Although the Order has had only a brief existence and its effects have not yet been measured through empirical investigation, that promise seems to have been realized. The Chief of Detectives of the Metropolitan Police Department has concluded that "since our department drew up uniform procedures for conducting police lineups, we have not had a single case dismissed for a bad or suggestive lineup identification. In fact, the courts in several cases have praised our lineups, upholding convictions that defense counsel sought to reverse." ${ }^{10}$ For example, in U.S. v. Perry the Court of Appeals said:

We also note that, after this case arose, the Metropolitan Police Department put into operation a regulation restricting on- and near-the-scene identification confrontations to suspects arrested within 60 minutes after the alleged offense and in close proximity to the scene. We see in this regulation a careful and commendable administrative effort to balance the freshness of such a confrontation against its inherent suggestiveness, and to balance both factors against the need to pick up the trail while fresh if the suspect is not the offender. We see no need for interposing at this time any more rigid time standard by judicial declaration. ${ }^{11}$

On a short term basis the impact of rulemaking will necessarily be to contract police authority since most departments presently use court decisions for establishing the outer limits of permissible conduct. But over time, this approach may lead to a standard of reasonableness as a measure of agency conduct that is more understanding and responsive to law enforcement needs than policy determined by the conventional process has been. If agency interests are carefully articulated in the form of binding policy, they will be more sympathetically considered by legislatures and courts when those bodies fashion policy affecting law enforcement.

At the very least, the promulgation of policy will serve to reduce the uneven enforcement that now characterizes so much of street policing. Particularly in areas of discretion where the critical decision is whether to make an arrest, as opposed to decisions relating to compliance with various Constitutional mandates, rulemaking will introduce a desirable element of consistency in decisionmaking. ${ }^{12}$ Experience has shown that the proper and consistent exercise of discretion in large bureaucracies simply will not arise out of the individual judgments of individual

\footnotetext{
${ }^{10}$ Pitts, How Sound Is Your Police Lineup?, FBI LAw Enforcement Bulletin, Dec. I97x, at 2.

${ }^{11}$ U.S. v. Perry, 449 F.2d I026, I037 (D.C. Cir. I97x). Referring specifically to this opinion, the American Bar Assaciation's Committee on police standards comments: "This type of policy-making by the police and its reception by the court is to be commended. Hopefully, it will serve as precedent to be followed elsewhere." ABA Comm. on the Police Function, Standards Relating to the Urban Police FuncTION, Standard 4.4, Comment (Tent. Draft March, r972).

${ }^{12}$ Cf. Davis, supra note 1 , at go.
} 
employees doing their best. It will result, if at all, from the development of overall agency policies.

There is another value that is enhanced by agency rulemaking; it concerns the education of command officials about the actual behavior of street personnel. In any large bureaucracy a substantial chasm develops between the decisions that top administrators confront and those faced by staff at the bottom levels. When the gap becomes too wide, the higher echelon is divorced from essential information about important agency functions such as field interrogation, treatment of juveniles, and vice enforcement. As a result, agency performance often suffers when decisions are made by subordinate officials who may have limited experience, education, and perspective. In the police world, this means that social values are weighed and balanced by individuals whose median education is 12.4 years ${ }^{13}$ and that command officials are never confronted with the concerns and limitations of their personnel.

Moreover, like other administrators, police administrators sometimes see advantages in the avoidance of policymaking-in not having policy in a given area, especially if that policy would be open to public scrutiny. This is understandable since there are obvious hazards in making policy. A rule may produce unforeseen and unwanted consequences or may have to be defended when it is applied to situations not contemplated by its drafters or may trigger unwarranted or extreme criticism from community groups that do not fully understand its character and reach. These are substantial risks, but they are risks that should be taken in order to protect the officer on the street. If, in fact, it is advantageous for an official to avoid taking a policy stand, there may be a concomitant hardship visited on some street patrolman due to the official's inaction. When that patrolman takes an action later determined to be improper-perhaps by the same official who avoided the issue in the first place-he has much to fear; a judgment for damages, dismissal, or even personal injury and loss of life may result as, for example, when the department has no rules for hot pursuit of automobiles or the use of firearms.

\section{Impact on the Courts}

The judicial activism of the last decade may be in part the result of the thin showing of expertise offered by law enforcement agencies to the appellate courts. Professor Anthony Amsterdam has argued that the absence of policymaking by the executive branch has forced the Supreme Court "into the role of lawmaker" and at the same time made "it virtually impossible for the Court effectively to play that role."14 Comparing the police to other administrative agencies, Amsterdam points out that the Court must carry extra weight in the police area:

In most areas of constitutional law the Supreme Court of the United States plays a backstopping role, reviewing the ultimate permissibility of dispositions and

13 TASK Force IO.

${ }^{16}$ Amsterdam, The Supreme Court and The Rights of Suspects in Criminal Cases, 45 N.Y.U.L. REv. 785,790 (1970). 
policies guided in the first instance by legislative enactments, administrative rules or local common-law traditions. In the area of controls upon the police, a vast abnegation of responsibility at the level of each of these ordinary sources of legal rulemaking has forced the Court to construct all the law regulating the everyday functioning of the police. ${ }^{15}$

To the extent that police practices reflect police policies, the courts will have an added advantage in deciding criminal cases-advance knowledge of the police practice in question and perhaps also its underlying rationale. When the court reviews an agency action, its deliberations are advanced by the very fact there is a regulation or rule that is in question. The court can view the rule in the context of its relation to other rules and can search out the judgments that underlie or oppose the acceptance of the rule. But when it is required to operate in an information vacuum, it is "deprived of the ability to make any coherent response to, or to develop any organized regulations of, police conduct."16 There is a way to relieve some of the distress that inheres in deciding cases on insufficient data about police procedures and their underlying motivations. To the extent that the judiciary seeks out police policy as an aid in its own decisionmaking, instead of focusing only on the conduct of the officers involved in a particular case, it can inspire more rulemaking by the police.

\section{II}

\section{The Mechanics of Rulemaking}

\section{A. The Drafting Process}

Of the various functions lawyers perform, drafting rules is one of the most demanding. This is particularly true in a police department where the concept of rulemaking is characteristically unknown, not well understood, or suspect. To promulgate rules in as amorphous an area of the law as automobile searches or eyewitnesses identification calls for a complex of legal skills which is often beyond the reach of any single lawyer. Judgments about specific police powers that the department may wish to expand, contract, stretch, or modify need to be made; and in order to make them, the draftsman must have an intimate understanding of existing police practices and the problems that inhere in these practices, an indepth knowledge of the case law, an awareness of prosecution policy in the area, an'd substantial communication skills.

The starting point for the draftsman is not a review of the decisional law or the legislative history of the relevant statutes; rather, it is the compilation of the types

\footnotetext{
${ }^{28} I d$.

${ }^{16}$ Id. at 79I. Cf. H. Goldstein, Trial Judges and The Police, $x_{4}$ Crume and Deninquency $x_{4}, 24$ (1968); Packer, The Courts, The Police, and The Rest of Us, 57 J. CRIM. L.C. \& P.S. 238 (1966); LaFave \& Remington, Controlling the Police: The Judge's Role in Making and Reviewing Law Enforce. ment Decisions, 63 MrCH. L. REv. 987 (1965).
} 
of recurring problems facing the officer on the street. These problems will be far more numerous than the topics reviewed by the courts because even in those areas most litigated there remain many problems regarding which policemen must routinely make decisions but which have not been considered by the judiciary. Moreover, if the draftsman starts with the legal authorities, the end result will be a document organized in categories meaningful to lawyers but not necessarily helpful to policemen who, by the nature of their vantage point, may see the same phenomena in rather different terms. For example, from a policeman's perspective it is easier to have in his hand a single set of rules dealing with all aspects of eyewitness identification-including on-the-street showups, the use of photographs, and court-ordered lineups-even though these topics might not be treated together in the table of contents of a traditional criminal procedure textbook. Of course, once the draftsman has selected and organized topics to reflect the concerns of street officers, he will be driven back to the law for instruction.

Once the draftsman is alerted to the common problems involved in an area, then difficult judgments as to what the desirable reach of police powers should be must be made. For example, in the area of eyewitness identification, the draftsmen of Memorandum Order No. 16 concluded that "regardless of the time of arrest there shall be no identifications or lineups conducted at police facilities without the specific authorization of the United States Attorney's Office." This restriction was not dictated by the case law but was born of the view that courts tend to be suspicious of events occurring within a precinct station. Since the draftsmen believed that no great burden would be imposed by banning such identifications, it seemed pointless to risk possible court reversals by allowing them. At the same time, because it was felt that there might be an unusual case of importance where delaying the lineup until a court order was obtained might affect the outcome, the rule contains an escape clause which permits the prosecutor to authorize a lineup at the precincts or headquarters.

In other areas the eyewitnesses identification order illustrates the conversion of judicial holdings, characteristically expressed in general terms, into concrete rules of thumb for the policeman to follow. Rule Number I provides in part that "if a suspect is arrested within 60 minutes of an alleged offense... he shall be returned to the scene of the offense, or the eyewitnesses shall be transported to the scene of the arrest, for identification of the suspect." The sixty minute rule is not the mandate of any judicial decisions specifying a given time. Rather the opinions speak in broader terms of "prompt" confrontations and "freshly" apprehended subjects." This general language possibly may be sufficient for the operation of a small group of highly trained officers such as the robbery squad, but it is inadequate for the functioning of a large metropolitan police department of $5^{100}$ men that investigates

\footnotetext{
${ }^{17}$ Russell v. United States, 408 F.2d I280, I284 (D.C. Cir. I969), cert. denied, 395 U.S. 928 (I969). Cf. United States v. Evans, 438 F.2d I62 (D.C. Cir. 197I, cert. denied, 402 U.S. 1010 (197I).
} 
800-1000 robberies a month. What these men need is a simple, easily-applied rule that is likely to result in an identification. In the judgment of the draftsmen, sixty minutes seemed to be the best time that the department could expect in light of previous appellate court opinions and the need to screen out unreliable identifications made too long after the event. Undoubtedly, application of the rule will cause problems in the prosecution of some cases. There will be cases in which the witness who could make an identification sixty-five minutes after the offense will have dimmed recollections by the time of the lineup. Similarly, there will be situations in which the delay will diminish the witness' willingness to get involved in what he now understands may be prolonged court proceedings. The occasional loss of a case is a fundamental hazard in the rulemaking process and can be rationalized only in terms of achieving overall higher performance in reducing the threat of robbery.

\section{B. Inputs From Outside the Department}

Because the concept of rulemaking by law enforcement agencies is new and not understood by many lawyers, it is likely to develop opposition from those who feel more comfortable with a case-by-case approach to crime control. At times, the district attorney will be troubled by the impact of a rule which limits his discretion in the processing of a case. He may perceive the rule as the cause of an acquittal in a particularly celebrated case. Unlike the chief of police who is most concerned about the overall level of crime in the community, the prosecutor is likely to be more interested in the outcome of individual cases. Thus there is the possibility of increased tension between police agencies and prosecutors as the boundaries of police discretion become better defined and more visible. But there is no reason to assume that prosecutors are the natural enemies of rulemaking. As time passes it is likely that the prosecutor will provide great assistance to the police both in the identification of the subject matter of rules and the actual content of the rules themselves.

Several commentators have urged that private parties should in some way be admitted to the rulemaking process, ${ }^{18}$ and there may indeed be some merit in not limiting deliberations to governmental representatives. In the District of Columbia, drafts of proposed orders have been circulated on an informal basis to members of the judiciary, the public defenders' office, the legal services program, and the American Civil Liberties Union; lawyers from these groups have made a contribution without delaying the issuance of the rules. But the question of whether private parties can make a contribution is a very different one from whether private parties should be allowed as a matter of right to participate in the rulemaking process. ${ }^{10}$

\footnotetext{
${ }^{18}$ For discussions of the advisability of public participation in the rule-making process, see DAvis, Administrative Justice (1969); MoGowan, Rule Making and The Police, 70 Mrch. L. Rev. 659 (1972); Amsterdam, supra note 14 , at 8ro.

${ }^{10}$ One of the few attempts by a law enforcement agency to involve citizens in the decision-making process, a proposal of the police department of Dayton, Ohio, to establish a "policy making and procedure definition program," was attacked by the Fraternal Order of Police as a thinly disguised
} 
It seems clear that unless private participation is carefully structured it contains not only opportunities to advanice rulemaking but also to impair it, particularly if the participants are not trained in the law and are unsophisticated about the issues involved. The question of private involvement should remain an open one. At this point in time, when the whole concept of rulemaking is in its infancy, there is no reason to inhibit its development by imposing citizen participation as a prerequisite to the promulgation of rules. Certainly, there is no support for mandatory citizen involvement in existing law, nor any basis in recent experience to believe that it will prove an unmixed asset. It would be adequate at present if police departments formulated policy statements and maintained them in a form which was available for public examination. Openness invites publicity and community reaction and insures that policy can be easily challenged in the courts. Such public access will promote the production of sophisticated, balanced policy positions. ${ }^{20}$ At a later date, when more experience is acquired, the advisability of allowing private groups and individuals to participate in the rulemaking process can be the subject of experimentation.

\section{III}

\section{EnForCing the RULES}

The problem of sanctions for violations of departmental rules has received limited attention in the few published articles concerning police rulemaking. ${ }^{21}$ The subject is a complex one, and a detailed discussion falls beyond the scope of this article. Nevertheless, because of its importance-especially now when the exclusionary rule is being critically re-examined and when there may be a majority on the Supreme Court favoring abandonment of the rule ${ }^{22}$-some comment is necessary.

At present, the rule operates to exclude evidence of a crime once it is judicially determined that a patrolman or detective has acted improperly in obtaining the evidence. Judicial review is performed without regard to whether the questioned conduct violated or conformed to departmental policy or whether, in fact, policy exists at all..$^{23}$ Also irrelevant to the operation of the rule is whether disciplinary

civilian complaint review board. Sergeant Fred Wade, the President of the Fraternal Order of Police, said that the proposal "suggests that a public task force approach ... will be taken. It further suggests that the entire community would be involved," not just police officials. Dayton Daily News, May 4, I97I. For an explanation of this innovative proposal, see Igleburger \& Schubert, Policy Making for the Police, 58 A.B.A.J. 307 (I972).

${ }^{20}$ At the same time, it seems clear that there are certain areas of police discretion that do not lend themselves to statements on the record. For example, it is questionable whether a particular agency's policy of tolerating speeding five miles per hour over the posted limit should be a matter of public pronouncement, or whether the department's policies regarding the uve of undercover agents and informants in vice enforcement should be known to the general public.

${ }^{21}$ See, e.g., MeGowan, supra note 18 , at 672, 681, 689.

${ }^{23}$ See generally, Oaks, Studying the Exclusionary Rule, 37 CHr. L. REv. 665 (1970). See also Bivens v. Six Unnamed Narcotics Agents, 403 U.S. 388 (I97I).

23 "In those cases in which the legality of police performance is questioned by the introduction of a motion to suppress cvidence, rulings are made in a manner which serves neither to influence 
action against the officer by the department is contemplated or even whether actual punishment, such as a fine, suspension, or dismissal, has already been imposed. Such an approach, it is suggested, does not contribute to the deterrence impact of the exclusionary rule because the conduct of the offending officer is not brought to the attention of his supervisors as a routine practice. There are no established mechanisms to communicate the results of judicial or prosecutorial decisions. Indeed, the officer himself may not be present in court at the time the decision to suppress evidence is made, nor even learn of it subsequently. The system of departmental discipline, whatever its reach, runs along an entirely different track than the exclusionary rule process, and prosecutors and judges do not view it as their job to communicate to the department adverse decisions resulting from police misconduct. ${ }^{24}$

A different approach would be to direct the thrust of the exclusionary rule to an evaluation of agency policy. Policy that is found to be deficient would be invalidated and the evidence still excluded; but in those cases where the policy itself is sound and it is the behavior of the individual officer that is wrong, then, it may be argued, no additional social values are advanced by suppressing reliable evidence of guilt if the department enforces its own rules and does not tolerate errant practices. To the extent that the exclusionary rule is grounded on the principle of deterrence, it may be that this goal can be achieved through internal discipline while allowing the trial to become a more straightforward search for truth.

Judge Carl McGowan has gone so far as to speculate that the existence of effective internal procedures might be a basis for discarding the principle of excluding evidence altogether:

The judges might say in effect to the police: If you can satisfy us that you are doing everything you can to reduce the incidence of violations through meaningful disciplinary action, we will no longer need to seek deterrence through the indirect sanction of exclusion. This would be sensible approach, since direct discipline

the future behavior of the officer nor to influence the policies and practices of the police agency. Judges seem content to consider each motion to suppress as a review of the conduct of individual officers, even when the officer's conduct appears to be consistent with departmental practices. Not only are the broader problems not addressed, but the suppression of evidence has no effect upon the behavior of the individual officer. Given this choice, the officer is likely to conform to the expectations of his most immediate superiors rather than of the courts. Goldstein, Administrative Problems in Controlling the Exercise of Police Authority, 58 J. CorrM. L.C. \& P.S. 168,169 (1967).

${ }^{26}$ The Metropolitan Police Department of the District of Columbia has recently created as part of its general counsel's office a case review unit with responsibility for searching out police practices that cause cases to be lost. This unit, staffed by a lieutenant and a sergeant with substantial investigative experience, is located in the prosecutor's office where it has access to the prosecutors' case jackets. It examines cases where a nol pros is taken, cases that are dismissed, and "cases where the prosecutor indicates that a deficiency in investigative techniques could have been remedied by sounder practice" The unit will also. seek to discern "patterns of behavior and routine practices that can be altered and improved." D.C. Metropolitan Police Departanent, Annuar Report of the General. Counser (March 10, 1971). The New York City Police Department has recently created a unit with similar functions. 
imposed by the police internally is far more likely to deter than remote exclusions of evidence in criminal trials. ${ }^{25}$

This observation is given added force if it is understood that the incentives for following departmental rules and procedures are not merely negative ones. It is true that violations of the Metropolitan Police Department orders on automobile searches or eyewitness identification will subject a man to discipline; but it is equally important, from the point of insuring compliance, to note that knowledge of the general orders of the department is closely tied to promotion as these orders form a large part of the material covered on the examinations for sergeant, lieutenant, and captain.

Another related issue arises with respect to police conduct which, although in accordance with law, violates a departmental rule. For example, assume that a department adheres to a policy that before a policeman can show the victim of a crime photographs of any suspects, he must first caution him "not to feel under any obligation to identify anyone" and that "justice is as equally served by clearing an innocent person as convicting a guilty one." Even though it is not required under existing law, department officials may desire such a rule because they feel it enhances the reliability of the identification process and creates an image of policemen as individuals committed to fair play. From a constitutional perspective, the problem first appears when an officer fails to give the cautionary instruction. Will his omission impair the admissibility of the identification; and, if so, will this retard the growth of rulemaking? The law is not sufficiently developed to give a certain answer. Perhaps the most that can be said is that although the principle that an agency must suffer the consequences of a failure to abide by its own rules has many precedents, ${ }^{26}$ its application to the criminal law and police rulemaking is not yet fixed.

\footnotetext{
${ }^{25}$ McGowan, supra note 18, at 69o. Along a similar path, Geoffrey M. Alprin, General Counsel to the Metropolitan Police Department of the District of Columbia, concludes that the "best alternative" to the exclusionary rule is a "system of internal regulation, by finite, comprehensible, departmental orders, to which our personnel can be held internally accountable. ... The point is that although the exclusionary rule has proved to be an unsatisfactory judicial technique, we in law enforcement cannot realistically expect that it will be abolished without some device created to replace it, and it is better for us to create that device than some other administrative agency or court. The answer for us seems to be our own internal orders, along with a mechanism to insure compliance with such orders by our personnel." Letter to John A. LaSota, Legal Advisor to the Chief of Police, Phoenix, Arizona, Feb. I5, I972.

${ }^{20}$ The leading case is United States ex rel. Accardi จ. Shaughnessy, 347 U.S. 260 (1954). See also Service v. Dulles, 354 U.S. 363 (I957); Vitarelli v. Seaton, 359 U.S. 535 (I959); United States v. Heffner, 420 F.2d 809 (4th Cir. I969); United States v. Leahey, 434 F.2d 7 (Ist Cir. I970). But see United States v. Luna, 313 F. Supp. I294 (I970), where the Court said: 'While the need to enforce rights granted by the Constitution and laws of the United States may outweigh the interests mitigating against the exclusion of otherwise admissible evidence, the enforcement of an agency policy statement does not, regardless of how desirable that policy might be. The Constitution and the laws may of necessity diatate preconditions for the admissibility of evidence in a federal trial; administrative agencies may not." Id at I295.
} 


\section{IV}

\section{Institutionaltzing Rulemaking in Law Enforcement Agencies}

Any discussion on the prospects of expanding the rulemaking process in police agencies must start with the manpower shortage. In terms of what needs to be done, the prospects for rapid change are bleak because there are very few lawyers or skilled lay draftsmen available on a full time basis to assist the more than 40,000 police departments in the United States. Even those few departments with large legal staffs that understand the value of rulemaking have difficulty researching and drafting more than a few major policy statements a year. The experience of the General Counsel's Office of the Metropolitan Police Department with the two orders referred to earlier is illustrative. Before either order was issued to the force, it was processed through more than nine separate drafts and was considered by command officials throughout the Department and by various criminal justice officials in the jurisdiction. The overall time for preparation ranged from three to five months. Authorship cannot be claimed by any single lawyer but is shared by at least three different attorneys and the many others who made significant contributions. For those departments that lack such ample resources the challenge of policymaking is stifled at the outset. The most energetic and progressive agencies, and even those that have staff lawyers available to research and write the regulations, suffer from a scarcity of skilled researchers and draftsmen.

The legal advisors across the country do provide a mechanism for the dissemination of policy; and, to a limited degree, some sharing of legal materials has occurred as a result of communication among legal advisors. But there are only Ioo legal units in the country, ${ }^{27}$ and most of these are one-man operations in which the advisor's time must be channelled to assignments other than rulemaking. Moreover, some legal advisors are action-oriented and spend much time on the street helping individual officers. These legal advisors, while not opposed to rulemaking, lack the inclination and sometimes the ability to devote much energy to it.

On the positive side, it is encouraging that the International Association of Chiefs of Police in its recently published Guidelines For A Police Legal Unit gives explicit recognition to the importance of rulemaking:

Important cases like Miranda, Chimel and Chambers often raise more questions than they answer. This is because the opinions deal with the facts of the cases decided, and broad guidelines are absent in the decisions. It is then necessary for the legal unit, in cooperation with the county prosecutor (and sometimes the courts), to draft procedural guidelines to implement judicial mandates. These directives may take the form of a legal training bulletin giving examples of the application of a recent court ruling, a general order directing members of the department

\footnotetext{
${ }^{27}$ INT'L Ass's of Chefs of Police, Guidelines for a Police Legal Unit 5 (W. Schmidt ed. r972).
} 
when and how to conform to the ruling, or a combination of both. This service is one of the most important ones a legal unit can perform. (emphasis added) ${ }^{28}$

And more change is in wind. The understanding of rulemaking by police officials is on the increase, legal advisors are growing in number, and the concept of rulemaking itself is likely to remain free of the controversy that has inhibited earlier proposals for reform. If it is fair to say that the promise of rulemaking is the promise of institutional reform, then it seems also safe to predict that slow and steady progress is likely to be made during the next decade. ${ }^{29}$

\section{CONCLUSION}

Policymaking by police administrators has been largely limited to relatively unimportant subject areas in which police experience is already well-defined. Officers

${ }^{28}$ Id. at 15 . The Guidelines also observe: "If the directive is thoroughly researched, carefully worded, and meticulously explained, it can serve as a guide to the judiciary as well. Judges need guidelines based on careful legal reasoning as much as policemen, and will be less likely to overrule a police practice adopted to implement a landmark court decision if the practice adopted in a written directive is baced on a well-written legal brief, covering the applicable points and authorities of law." Id.

${ }^{20}$ The grant from the Police Foundation to the law school at Arizona State University creating a Project on Law Enforcement Policy and Rulemaking is designed to accelerate the growth of rulemaking. Under the terms of the grant, legal services will be provided to approximately ten large city police departments that have expressed an interest in rulemaking.

Among the areas suggested for rulemaking by the chiefs of the ten departments and their legal advisors are: (I) service of arrest and search warrants (and the attendant problems of securing the premises and dealing with property damage); (2) problems associated with stop-and-frisk and field interrogation; (3) modifications of the existing disciplinary system, with appropriate balancing of rights for the accused officer; (4) fingerprinting policies; (5) the settlement of minor disputes among neighbors and within the family; (6) development of a citation and summons system; (7) problems assaciated with vagrancy and disorderly conduct type statutes; (8) policies relating to freedom of assembly and restraints on gatherings, with particular reference to the development of standards and conditions for the issuance of permits.

In some cases the proposed problem area was one that had been subjected to much consideration by other law enforcement agencies, but the police official suggesting the topic was unaware of this. For example, one police official commented that, although it might be desirable to restrict the common law rules regarding the use of firearms, the task of drafting such regulations would call for too subtle and delicate judgments and the end product would not provide sufficient guidance to the officer on the street.

Absent extraordinary circumstances, no assignment is being undertaken by the Project unless enthusiasm for it is registered by several of the participating law enforcement agencies. All the research is "action-oriented" in the sense that the implementation of policy statements is the ultimate goal, but the impetus for action lies with the agency officials.

The chiefs of each of the participating agencies have designated a high-ranking liaison official, most commonly the legal advisor, to meet with Center staff on a regular basis and provide direction to them. The liaison official's role is to propose subjects for regulation, review draft regulations for soundness of policy, and, in general, lay the foundation for adoption of the regulation by his department. This official has principal responsibility for soliciting the comments of other local, criminal justice officials, for example, the city attorney and public defender, and other public officals such as the city manager, members of the city council, or local judges.

There has been some positive experience with this type of legal assistance in the federal government. The Legal Services Division of the Office of Economic Opportunity as part of a broad-based effort to elevate the quality of legal services provided to indigents by the over two hundred OEO-funded programs established technical assistance centers at universities across the country; each specialized in a different substantive area of law. It is generally agreed that these national centers-staffed by lawyers with expertise in a given field-made a difference in overall attorney performance. Even in legal areas as locally- 
on patrol are not provided with a set of understandable rules to guide them in responding to the difficult situations which they routinely confront. Consequently, the individual patrolman is forced to make his own decisions on matters that require the most delicate balancing of important social and legal values. Against this background, the adoption of clearly articulated, internal rules to govern police action offers the prospect of significant benefit for the law enforcement institution. The advantage of comprehensive rulemaking will be felt on many levels of the police structure. The patrolman would obtain the protection of specific rules which justify his conduct, and thereby be relieved both of the burden of having to identify for himself the legal standards which support his official actions, and of being penalized, by civil suit or internal discipline, for taking action later deemed improper. Moreover, by the adoption of rules applicable to the entire community, the departmental goal of uniformity of enforcement will be advanced. Perhaps most importantly, by taking the initiative in rulemaking, the department will be able to advance positive policies, rather than only reacting to the pressures imposed by other branches of government and the community. Rulemaking permits law enforcement agencies to create policies that will be more responsive to police needs than many of those presently imposed on the police.

The police should also benefit from the influence which intelligent, welldelineated policies will have on judicial bodies reviewing police action. The judiciary will be prompted to consider police conduct not as an isolated, unique event, but rather in the context of the accompanying regulations and in the light of a policearticulated rationale for the rule.

Although the positive effects of policy formation on the patrolman, the department, and the judiciary are substantial, progress is not likely to come quickly, as the rulemaking process in law enforcement is not yet widely understood or accepted, nor does a reservoir of skilled draftsmen now exist. Moreover, the rulemaking process, particularly if it involves nongovernmental participation, is inherently a long one.

In the process of defining a rulemaking function for law enforcement agencies, it should be remembered that the ultimate beneficiaries will be the citizens of the community served. As officers receive clearer indications of the scope of their discretion, and as policy becomes more sophisticated and responsible, it is likely that policemen will be able to perform their tasks with greater efficiency, confidence, and acceptance. And while it cannot be hoped that controversies concerning the exercise of police discretion will ever be eliminated, the rulemaking approach does represent a promotion of democratic values in that it gives public visibility to the rules governing difficult law enforcement problems.

grounded as housing, consumer rights, and education, the experience has been that the problems surfaced by programs in very different parts of the country may well yield to similar solutions. 